\title{
Neuroprotective Effect of Phyllanthus acidus L. on Learning and Memory Impairment in Scopolamine-Induced Animal Model of Dementia and Oxidative Stress: Natural Wonder for Regulating the Development and Progression of Alzheimer's Disease
}

\author{
Md. Sahab Uddin', Abdullah Al Mamun1, Md. Saddam Hossain1, \\ Muhammad Ashaduzzaman', Md. Ali Asif Noor', Md. Sarwar Hossain², \\ Md. Josim Uddin ${ }^{3}$, Jyotirmoy Sarker4, Md. Asaduzzaman ${ }^{1 *}$ \\ ${ }^{1}$ Department of Pharmacy, Southeast University, Dhaka, Bangladesh \\ ${ }^{2}$ Department of Pharmacy, State University of Bangladesh, Dhaka, Bangladesh \\ ${ }^{3}$ Department of Pharmacy, International Islamic University Chittagong, Chittagong, Bangladesh \\ ${ }^{4}$ Department of Pharmacy, Jagannath University, Dhaka, Bangladesh \\ Email: msu-neuropharma@hotmail.com, ,asadph14@yahoo.com
}

Received 12 January 2016; accepted 20 May 2016; published 16 June 2016

Copyright (C) 2016 by authors and Scientific Research Publishing Inc.

This work is licensed under the Creative Commons Attribution International License (CC BY).

http://creativecommons.org/licenses/by/4.0/

(c) (i)

Open Access

\section{Abstract}

Nature is the best source of complementary and alternative medicine. The plant Phyllanthus acidus (PA) $L$. has been used traditionally in pain, inflammatory and oxidative stress related disorders. In this consequence, methanolic extract of PA (MEPA) was selected to explore the ability of this plant to enhance cognitive function, brain antioxidant enzymes and anti-acetylcholinesterase activity which can be used for the treatment of oxidative stress related disorders like Alzheimer's disease (AD). The purpose of this study was to investigate the neuroprotective effect of MEPA on learning and memory impairment in scopolamine-induced rats of dementia and oxidative stress. Treatment with MEPA (i.e., 100 and $200 \mathrm{mg} / \mathrm{kg} \mathrm{b.w.)} \mathrm{was} \mathrm{investigated} \mathrm{in} \mathrm{scopolamine-treated}$ Swiss albino male rats for 14 days and its neuroprotective effects were examined using Elevated Plus Maze (EPM) test, Passive Avoidance (PA) test, Novel Object Recognition (NOR) test, Morris Water Maze (MWM) test as well as level of antioxidant enzymes such as catalase (CAT), super oxide dismutase (SOD), glutathione reductase (GSR), glutathione-S-transferase (GST), reduced glutathione (GSH), glutathione peroxidase (GSH-Px), lipid peroxidation (TBARS) contents and 
acetylcholinesterase (AChE) activity in rat brain tissue homogenates. Administration of MEPA significantly $(P<0.05, P<0.01 ; P<0.01)$ decreased RTL (retention transfer latency) in rats on $7^{\text {th }}$ and $14^{\text {th }}$ day compared to the disease control and control group in the EPM test. In PA test the doses of MEPA suggestively $(\mathrm{P}<0.05, \mathrm{P}<0.001$; $\mathrm{P}<0.05, \mathrm{P}<0.01)$ increased $\mathrm{STL}$ (step-through latency) in rats on $7^{\text {th }}$ and $14^{\text {th }}$ day with respect to disease control and control group. For NOR test administration of MEPA considerably $(P<0.01, P<0.001 ; P<0.01)$ increased the DI (discrimination index) in rats with respect to that of disease control and control group. The doses of MEPA markedly $(\mathrm{P}<0.05, \mathrm{P}<0.01 ; \mathrm{P}<0.01)$ decreased EL (escape latency) and significantly $(\mathrm{P}<0.01, \mathrm{P}$ $<0.001 ; \mathrm{P}<0.05, \mathrm{P}<0.01$ ) increased TSTQ (time spent in the target quadrant) on successive days as compared to that of disease control and control group in the acquisition trial of MWM test. In case of probe trial of MWM test MEPA administration considerably $(\mathrm{P}<0.01 ; \mathrm{P}<0.05, \mathrm{P}<0.01)$ increased TSTQ and significantly $(\mathrm{P}<0.05, \mathrm{P}<0.01 ; \mathrm{P}<0.05, \mathrm{P}<0.01)$ increased TSA (time spent in the annuli) in rats on successive days as compared to that of disease control and control group. MEPA administration significantly $(\mathrm{P}<0.05, \mathrm{P}<0.01, \mathrm{P}<0.001 ; \mathrm{P}<0.05, \mathrm{P}<0.01)$ increased the level of CAT, SOD, GSR, GST GSH, GSH-Px and markedly $(\mathrm{P}<0.01 ; \mathrm{P}<0.01, \mathrm{P}<0.001)$ decreased TBARS level through inhibiting lipid peroxidation as well as significantly $(\mathrm{P}<0.01, \mathrm{P}<0.001 ; \mathrm{P}<$ $0.05, P<0.01, P<0.001)$ decreasing AChE activity in rats brain compared to the disease control and control group. The present study demonstrates that MEPA showed the neuroprotective effect by improving cognitive functions and reduces oxidative stress by increasing the level of brain antioxidant enzymes as well as decreasing lipid peroxidation and acetylcholinesterase activity. Therefore, this plant extract can be used for enhancing learning, memory, antioxidant potentiality and anti-acetylcholinesterase activity in neurodegenerative disorders like AD.

\section{Keywords}

Neuroprotective, Phyllanthus acidus, Antioxidant Enzyme, Dementia, Oxidative Stress, Acetylcholinesterase Activity, Alzheimer's Disease

\section{Introduction}

Cognition is a process of storing arrangement of facts in a regular method by which one becomes attentive of their surroundings, objects and views [1]. Impairment of cognition is one of the foremost health complications in normal aged life along within some neurological disease conditions, including Alzheimer's disease (AD) [2]. $\mathrm{AD}$ is an age-related progressive neurodegenerative disorder which is associated with the unavoidable loss of cognitive function. This is the most common form of dementia, accounting for approximately $60 \%$ of all cases of impairing memory [3]. Globally at present 30 million people are affected by this disease and it is estimated that by 2050 more than 115 million people will have dementia [4] [5]. This disease is characterized by deposition of senile plaques, amyloid- $\beta$ (A $\beta$ ) and development of neurofibrillary tangles (NFTs) in the cerebral cortex and subcortical gray matter [6]. Alzheimer patient's brain has elevated levels of acetylcholinesterase (AChE), which is responsible for the breakdown of acetylcholine (ACh). ACh is a neurotransmitter which plays an important role for proper functioning of the central cholinergic system [7]. There is no treatment for AD. However, some AChE inhibitors such as physostigmine, tacrine and donepezil may help keep symptoms from getting worse for a limited time [6]. Therefore, it is lucrative to explore the usefulness of medicinal plants for the treatment of various cognitive disorders.

Scopolamine is a tropane alkaloid which has been commonly injected intraperitoneally to study cognitive deficits in experimental animals. It is structurally similar to the neurotransmitter acetylcholine and exerts its function by blocking the muscarinic acetylcholine receptors that lead to cholinergic dysfunction and impaired cognition [8]. In recent times, many studies stated that memory impairment in the scopolamine-induced animal model is linked with increased oxidative stress within the brain due to an alteration of brain antioxidant enzymes [9]-[11]. Increasing evidence highlights that free radical mediated oxidative stress is responsible for AD [12]. In order to lead a normal life, oxidation is necessary for biological reactions or processes that lead to generation of reactive oxygen species (ROS) as byproducts. Proper functioning of the human body depends on the redox ho- 
meostasis i.e., the balance between oxidation and antioxidation [13]. In case of late-onset sporadic AD, imbalances between oxidation and antioxidant factors induce cellular and molecular abnormalities [14]. The neuronal network i.e., brain is more prone to the oxidative damage because of a high level of long chain polyunsaturated lipids in neuronal cell membranes, high oxygen consumption, high metabolic rate of transitional metals and poor antioxidative defense [15] [16]. Several studies have suggested that after oxidative stress, senile plaques and NFTs are formed both of which are neuropathological stamps of AD [17]. In addition to this, the antioxidant defenses of the brain are modest. The content of catalase (CAT), glutathione peroxidase (GSH-Px) and vitamin $\mathrm{E}$ in the brain is less as compared to liver [18].

Antioxidants are exogenous or endogenous substances that prevent oxidation and act against oxidative stress associated deleterious effects on the cellular system [19]. Antioxidants are also associated in scavenging free radical, preventing free radical chain reactions and improve antioxidant status in patients [20]. In order to prevent or slow the progression of free radical mediated oxidative stress, brain antioxidant defense enzymes such as, catalase (CAT), glutathione peroxidase (GSH-Px), glutathione reductase (GSR), reduced glutathione (GSH) and glutathione-S-transferase (GST) play an important role [21]. In recent years there has been increased interest in the therapeutic use of antioxidants in the treatment of disease associated with free radical mediated oxidative stress. As said by the World Health Organization (WHO) more than $80 \%$ of the world's population trusts on complementary and alternative medicine for their medical care [22]. The folkloristic concepts of medicinal plants play an active role in the treatment of various medical conditions. The use of medicinal plant and plant products is increasing day by day. About 3.5 billion people in developing countries, primarily depended on medicinal plants and herbal medicine around for their healthcare needs [23]. On the other hand, in Western society the rejection of synthetic or biomedical products has become a growing trend and allowed for a rise in the demand for natural medicines [24]. In the treatment of cognitive dysfunctions associated with age and neurodegenerative disorder the phytoconstituents of medicinal plants play a central part. In the treatment of AD medicinal plants such as Ginkgo biloba, Bacopa monnieri and Huperzia serrata has been widely examined [25]-[27].

The plant Phyllanthus acidus (PA) L. is known in Bengali as Orbori belongs to the family Phyllanthaceae has been explored for cognitive activity [28]. This plant is widely found in Bangladesh, South India and Southeast Asian countries [29]. Fruit are drupaceous, oblate, shallowly 6- or 8-lobed, greenish yellow to creamy-white color, containing 6 to 8 smooth seeds [30]. This plant has been used traditionally in the treatment of several pain, inflammatory and oxidative stress related disorders such as fever, rheumatism, bronchitis, asthma, respiratory disorder, hepatic disease, diabetes, gonorrhea and gastrointestinal tract disorders [31]. Phyllanthus genus is highly enriched in various phytoconstituents like alkaloids, phenolics, flavonoids, tannins, terpenes and lignans [32]. Different parts of PA have been reported for excellent medicinal properties. The leaves of the plant stated to possess antihypertensive, antimicrobial, hepatoprotective activity and also used as an antidote to viper venom [33]. The root and seed of the plant are useful as cathartic, bark and roots are used to treat fever traditionally [34]. The latex of the plant is recognized with purgative and emetic activity [35]. The fruits are used as memory enhancer, blood purifier, appetite stimulant, relief of coughing and preventive action against diabetes [36].

Previous studies showed that fruits of this plant showed antioxidant, memory enhancing, anti-cholinesterase, astringent, hepatoprotective, cytotoxic and antimicrobial activity [37]. Therefore this study was designed to investigate the neuroprotective effect of MEPA on learning and memory impairment in scopolamine-induced rats by behavioral studies such as Elevated Plus Maze (EPM) test, Passive Avoidance (PA) test, Novel Object Recognition (NOR) test, Morris Water Maze (MWM) test as well as the activity of antioxidant enzymes by biochemical studies such as catalase (CAT), superoxide dismutase (SOD), glutathione peroxidase (GSH-Px), glutathione reductase (GSR), glutathione-S-transferase (GST), reduced glutathione (GSH), estimation of lipid peroxidation (TBARS) and acetylcholinesterase (AChE) activity in rat brain tissue homogenates.

\section{Materials and Methods}

\subsection{Chemicals and Drugs}

Acetyl thiocholine iodide (ATCI), 5,5-dithiobis-2-nitrobenzoate ion (DTNB), trisfamino methane hydrochloride (Tris-HCl), bovine serum albumin (BSA), phenazinemethosulphate sodium pyrophosphate, sodium azide, glutathione reductase, oxidized glutathione, reduced glutathione (GSH), ethylenediaminetetraacetic acid (EDTA), nicotinamide adenine dinucleotide phosphate (NADPH), 1-chloro-2,4-dinitrobenzene (CDNB), trichloroacetic acid (TCA), thiobarbituric acid (TBA) and trichloroacetic acid all were purchased from Sigma-Aldrich, USA. 
Unless otherwise specified, all other chemicals were of analytical grade. Donepezil hydrochloride powder was obtained from Incepta Pharmaceuticals Ltd. as gift and scopolamine butylbromide injection (Butapan ${ }^{\circledR}$ ) with a label claim $20 \mathrm{mg} / \mathrm{ml}$ was purchased from retail pharmacy of Dhaka city in Bangladesh.

\subsection{Collection and Identification of Plant Materials}

The leaves of PA were collected from Kapasia, Gazipur, Bangladesh, in August, 2014. After collection leaves were then washed properly to remove dirty materials and identified by expert of Bangladesh National Herbarium, Mirpur, Dhaka, Bangladesh. Accession number: DACB-40181 for PA.

\subsection{Drying and Grinding of Plant Materials}

The fresh fruits of the plant after collection were cut into small pieces, sun dried for 7 days and finally dried in an oven at temperature not more than $50^{\circ} \mathrm{C}$ for better grinding. After drying, the entire portions were ground into coarse powder by a grinding machine and stored in an airtight container for further uses.

\subsection{Extraction of Plant Materials}

Powdered plant materials (fruits) having a weight of about $500 \mathrm{~g}$ were taken in an amber colored glass bottle and soaked in 1.5 liter of $98 \%$ methanol at room temperature. The bottle with its contents were sealed and kept for a period of about 7 days with occasional shaking and stirring. The whole mixture was then filtered through cotton and then through Whatman No. 1 filter paper and was concentrated with a rotary evaporator under reduced pressure at $50^{\circ} \mathrm{C}$ temperature to give crude extract (12.542 g).

\subsection{Animals}

Swiss albino male rats were used in the present study. 56 Swiss rats of weighing around 180 - $230 \mathrm{~g}$ were purchased from ICDDR,B, Dhaka, Bangladesh. The animals were kept in cages (3 rats per case) under standard laboratory conditions with alternating light and dark cycle of $12 \mathrm{hrs}$ each. Food and water were supplied timely. The care and use of the animals were followed according to the guide for laboratory animals of the National Institutes of Health (NIH) [38]. The protocol of the experiment was approved by the animal ethics committee of the Department of Pharmacy, Southeast University, Dhaka, Bangladesh.

\subsection{Administration of Drugs and Test Compounds}

Donepezil hydrochloride was used as standard drug. A solution of donepezil hydrochloride was made by normal saline (pH 7.4) and administered orally (p.o.) to rats at $1 \mathrm{mg} / \mathrm{kg}$ body weight (b.w.). Scopolamine butylbromide was administered intraperitoneally (i.p.) to rats at $1 \mathrm{mg} / \mathrm{kg}$ body weight. Weighed quantity of MEPA was suspended in normal saline (pH 7.4) and administered orally to rats at 100 and $200 \mathrm{mg} / \mathrm{kg} \mathrm{b.w.} \mathrm{The} \mathrm{doses} \mathrm{of} \mathrm{the}$ donepezil hydrochloride, scopolamine butylbromide and MEPA were adjusted based on literature searches [37] [39]-[41]. Drug and the suspension of extract were prepared freshly every day and administered 30 min prior to experiment.

\subsection{Experimental Design}

Rats were divided randomly into eight groups with 6 rats in each as follows:

Group 1: In case of this group standard food and water were administered to rats (Con).

Group 2: In case of this group scopolamine butylbromide at a dose of $1 \mathrm{mg} / \mathrm{kg}$ b.w. was administered intraperitoneally to rats (Sco).

Group 3: In case of this group donepezil hydrochloride at a dose of $1 \mathrm{mg} / \mathrm{kg}$ b.w. was administered orally to rats (Don).

Group 4: In case of this group plant extract at a dose of $100 \mathrm{mg} / \mathrm{kg}$ b.w. was administered orally to rats (MEPA 100).

Group 5: In case of this group plant extractat a dose of $200 \mathrm{mg} / \mathrm{kg}$ b.w. was administered orally to rats (MEPA 200).

Group 6: In case of this group scopolamine butylbromide at a dose of $1 \mathrm{mg} / \mathrm{kg}$ b.w. and plant extract at a dose 
of $100 \mathrm{mg} / \mathrm{kg}$ b.w. were administered to rats (Sco + MPA 100).

Group 7: In case of this group scopolamine butylbromide at a dose of $1 \mathrm{mg} / \mathrm{kg}$ b.w. and plant extract at a dose of $200 \mathrm{mg} / \mathrm{kg}$ b.w. were administered to rats (Sco + MPA 200).

Group 8: In case of this group scopolamine butylbromide at a dose of $1 \mathrm{mg} / \mathrm{kg}$ b.w. and donepezil hydrochloride at a dose of $1 \mathrm{mg} / \mathrm{kg}$ b.w. were administered to rats (Sco + Don).

\subsection{Acute Toxicity Study}

The rats were divided into 4 groups, with 6 rats per groups. Normal saline was used as a vehicle to make suspension of the extracts. Rats were treated with the extract only once at a dose of 5, 50, 300 and $2000 \mathrm{mg} / \mathrm{kg} \mathrm{b.w.}$ Rats were fasted for 3 to 4 hrs before the administration of extracts but only water was supplied and after the administration food was withdrawn for 1 to 2 hrs. Rats were observed next 24 hrs for any behavioral, neurological profiles and 14 days for mortality. The acute toxicity study of the extracts was performed according to the guidelines of the Organisation for Economic Cooperation and Development (OECD) [42].

\subsection{Behavioral Study}

One week training was performed in rats in order to prepare them for behavioral study. During the training period only food and water were administered to rats. The fully trained rats were choice for the study. Studies were done between 10.00 am and $3.00 \mathrm{pm}$ in a soundproof room.

\subsubsection{Elevated Plus Maze (EPM) Test}

The spatial long-term memory of rats was assessed by using the EPM test [43]. A typical EPM apparatus consists of two open arms (length $500 \mathrm{~mm} \times$ width $100 \mathrm{~mm}$ ) and two close arms (length $500 \mathrm{~mm} \times$ width $100 \mathrm{~mm} \times$ height of the side walls $400 \mathrm{~mm}$ ). The maze was elevated to the height of $500 \mathrm{~mm}$ from the floor. In the middle of the maze the arms were connected by a central square [44]. During the acquisition trial each rat was placed individually at the end of an open arm facing away from the central platform and the time it took to move from the end of open arm to either of the closed arms was recorded as initial transfer latency (ITL) using a stopwatch. If the rat did not enter into one of the closed arm within $300 \mathrm{sec}$, it was pushed on the back into one enclosed arm and the transfer latency was given as $300 \mathrm{sec}$. Later the rat was allowed to explore the apparatus for $30 \mathrm{sec}$ to become familiar with the maze and then returned to its home cage. The retention trial followed 24 hrs after the acquisition trial in which time it took to move from the end of open arm and re-enter into either of the closed arms was recorded as retention transfer latency (RTL) using a stopwatch [45]. To remove any olfactory clue after each test, the apparatus was cleaned with 70\% ethanol [46].

\subsubsection{Passive Avoidance (PA) Test}

The emotional memory of rats based on contextual fear conditioning learning and instrumental learning was assessed by using the PA test [47]. A typical PA apparatus consists of a light compartment (depth $270 \mathrm{~mm} \times$ width $370 \mathrm{~mm} \times$ height $360 \mathrm{~mm}$ ) and a dark compartment (depth $270 \mathrm{~mm} \times$ width $370 \mathrm{~mm} \times$ height $360 \mathrm{~mm}$ ). A sliding door having $90 \mathrm{~mm}$ of diameter was situated in the middle part of the apparatus. The floor of this apparatus was consisted of steel bars with a diameter of $0.3 \mathrm{~cm}$ spaced $0.6 \mathrm{~cm}$ apart. A shock generator was connected to the steel bars, able to generate shock in the range of $0.5 \mathrm{~mA}$ [48]. In the acquisition trial, a rat was placed in the light compartment and when the rat entered into the dark compartment, the door was closed and an electrical foot shock of $0.5 \mathrm{~mA}$ was given for $3 \mathrm{sec}$ [49]. The time taken to enter the dark compartment was recorded as transfer latency (TL) using a stopwatch. Instantly after the shock, the rat was returned back to the home cage. The retention trial followed 24 hrs after the acquisition trial in which no shock was given when the rat entered the dark compartment and latency times to re-enter the dark chamber was measured as step-through latency (STL). If the rat did not enter into the dark compartment within $300 \mathrm{sec}$, its STL was measured as $300 \mathrm{sec}$ [50]. To remove any olfactory clue after each test, the apparatus was cleaned with 70\% ethanol [46].

\subsubsection{Novel Object Recognition (NOR) Test}

The object recognition memory of rats was assessed by using the NOR test, [51] which was box shaped apparatus (depth $70 \mathrm{~cm} \times$ width $50 \mathrm{~cm}$ width $\times$ height $40 \mathrm{~cm}$ ). Metal triangular $(8.5 \times 5 \times 14 \mathrm{~cm})$ and rectangular prisms $(5 \times 5 \times 14 \mathrm{~cm})$ were used as objects. Each test consists of two distinct trials such as training session and 
test session. At the start of the trial two identical objects were introduced into the apparatus. For the training sessions, each rat was placed in the apparatus and allow to explore the objects for a period of $\geq 10$ sec. Object exploration was determined when the rat sniffed and or touched the object $<2 \mathrm{~cm}$ from its nose. After that the rat was returned to its home cage. Before the test session one of the identical objects was replaced by a novel object and placed randomly. A test session was performed after 24 hrs of the training session, in which rat was allowed to explore the novel and familiar object for $4 \mathrm{~min}$. Exploration times of novel and familiar object was used for to determine the discrimination index (DI) [52]. The apparatus was cleaned after each test with $70 \%$ ethanol to remove any olfactory clue.

\subsubsection{Morris Water Maze (MWM) Test}

The spatial learning and memory of rats were assessed by using the MWM test [50]. A typical MWM apparatus consists of a circular tank made of polypropylene with a diameter of $1700 \mathrm{~mm}$ and depth of $450 \mathrm{~mm}$. The maze was divided into four quadrants in which a target platform with a diameter of $110 \mathrm{~mm}$ and $250 \mathrm{~mm}$ high was placed in one compartment. The tank was filled with opaque water to a depth of $260 \mathrm{~mm}$ in order to make the platform submerged, approximately $1 \mathrm{~cm}$ below the water surface [53]. For acquisition trial, in the middle of a compartment of the tank a rat was placed and a stopwatch was used to record the time it took to mount onto the submerged platform to determine the escape latency (EL). If the rat defaulted to detect the platform within $300 \mathrm{sec}$, it was directed toward the platform. A rat was permitted to stay on the platform for 30 sec in both cases [54]. Every day in random order with a different starting point, each rat was subjected to four successive trials remaining static the platform (east) as specified in Table 1. A stopwatch was also used to record the time spent in the target quadrant (TSTQ). After the end of the fourth trial, the rat was dried with a soft cloth and kept warm under a 150-Watt bulb within the home case [54].

A probe trial was performed for $60 \mathrm{sec}$ after the fourth trial of the last day $\left(14^{\text {th }}\right.$ day) in which the platform was removed. TSTQ and time spent in the annuli (TSA) were measured in which all rats were started from the same start point (west) in the probe trial [55].

Table 1. The sequence of trials during the study period of WMM test.

\begin{tabular}{ccccccc}
\hline $1^{\text {st }}$ day & $2^{\text {nd }}$ day & $3^{\text {rd }}$ day & $4^{\text {th }}$ day & $5^{\text {th }}$ day & $6^{\text {th }}$ day & $7^{\text {th }}$ day \\
\hline Q1 & Q2 & Q3 & Q4 & Q1 & Q2 & Q3 \\
Q2 & Q3 & Q4 & Q1 & Q2 & Q4 \\
Q3 & Q4 & Q1 & Q2 & Q3 & Q4 & Q2 \\
Q4 & Q1 & Q2 & Q3 & Q4 & Q1 \\
\hline
\end{tabular}

\subsection{Biochemical Study}

The rats were sacrificed under light anesthesia on $15^{\text {th }}$ day and whole brain was collected. The immediately collected whole brains were placed on an ice-chilled petri dish for cleaning and then cerebellum was rapidly removed from the whole brain tissue and the remaining brain was washed with ice cold sterile normal physiological saline $(0.9 \% \mathrm{NaCl})$. A $10 \%$ brain homogenate was prepared by using $30 \mathrm{mM}$ sodium phosphate buffer (pH 7.4) in a homogenizer. Then the homogenate was centrifuged at 20,000 RPM for $2 \mathrm{hrs}$ at $4^{\circ} \mathrm{C}$ to remove cellular debris and the supernatant was used for further studies. The protein concentration was determined by using bovine serum albumin (BSA) [56].

\subsubsection{Catalase (CAT) Activity}

The CAT activity was assessed by the method of Chance and Maehly with some modification [57]. The reaction mixture for this test was consisted of $2.5 \mathrm{ml}$ of $50 \mathrm{mM}$ phosphate buffer having pH 5.0, $0.4 \mathrm{ml} \mathrm{of} 5.9 \mathrm{mM} \mathrm{H}_{2} \mathrm{O}_{2}$ and $0.1 \mathrm{ml}$ of $10 \%$ brain homogenate. After $1 \mathrm{~min}$ incubation the changes in absorbance of the reaction mixture were determined by using spectrophotometer at $240 \mathrm{~nm}$. One unit of CAT activity was defined as an absorbance change of 0.01 as $\mathrm{U} / \mathrm{min}$.

\subsubsection{Super Oxide Dismutase (SOD) Activity}

The SOD activity was assessed by the method of Kakkar et al., [58]. The reaction mixture for this test was con- 
sisted of $0.1 \mathrm{ml}$ of $186 \mu \mathrm{M}$ phenazinemethosulphate, $1.2 \mathrm{ml}$ of $0.052 \mathrm{mM}$ sodium pyrophosphate buffer having pH 7.0 and $0.3 \mathrm{ml}$ of supernatant after centrifugation $(1500 \times \mathrm{g}, 10 \mathrm{~min}$ followed by 10,000 $\times \mathrm{g}, 15 \mathrm{~min})$ of $10 \%$ brain homogenate. In order to start enzyme reaction $0.2 \mathrm{ml}$ of $780 \mu \mathrm{M}$ NADH was added to the reaction mixture. After 1 min incubation enzyme reaction was stopped by adding $1 \mathrm{ml}$ of glacial acetic acid. The changes in absorbance of the reaction mixture were determined by using spectrophotometer at $560 \mathrm{~nm}$ and expressed as U/mg protein.

\subsubsection{Glutathione Reductase (GSR) Activity}

The GSR activity was assessed by the method of Carlberg and Mannervik [59]. The reaction mixture for this test was consisted of $1.65 \mathrm{ml}$ of $0.1 \mathrm{M}$ phosphate buffer having $\mathrm{pH}$ 7.6, $0.1 \mathrm{ml}$ of $0.5 \mathrm{mM}$ EDTA, $0.1 \mathrm{ml}$ of $0.1 \mathrm{mM}$ NADPH, $0.05 \mathrm{ml}$ of $1 \mathrm{mM}$ oxidized GSH and $0.1 \mathrm{ml}$ of $10 \%$ brain homogenate. The changes in absorbance of the reaction mixture i.e., disappearance of $\mathrm{NADPH}$ at $25^{\circ} \mathrm{C}$ were determined by using spectrophotometer at 340 $\mathrm{nM}$ and expressed as nM NADPH oxidized/min/mg protein using a molar extinction coefficient of $6.22 \times 10^{3}$ $\mathrm{M}^{-1} \mathrm{~cm}^{-1}$.

\subsubsection{Glutathione-S-Transferase (GST) Activity}

The GST activity was assessed by the method of Habig et al., [60]. The reaction mixture for this test was consisted of $1.475 \mathrm{ml}$ of $0.1 \mathrm{M}$ phosphate buffer having $\mathrm{pH}$ 6.5, $0.025 \mathrm{ml}$ of $1 \mathrm{mM}$ CDNB, $0.2 \mathrm{ml}$ of $1 \mathrm{mM}$ reduced GSH and $0.3 \mathrm{ml}$ of $10 \%$ brain homogenate. The changes in absorbance of the reaction mixture were determined by using spectrophotometer at $340 \mathrm{~nm}$ and expressed as nM CDNB conjugate formed/min/mg protein using a molar extinction coefficient of $9.6 \times 10^{3} \mathrm{M}^{-1} \mathrm{~cm}^{-1}$.

\subsubsection{Reduced Glutathione (GSH) Activity}

The GSH activity was assessed by the method of Jollow et al., [61]. For this test $1.0 \mathrm{ml}$ of $10 \%$ brain homogenate was precipitated with $1.0 \mathrm{ml}$ of $4 \%$ sulfosalicylic acid. The samples were kept at $4^{\circ} \mathrm{C}$ for $1 \mathrm{hrs}$ and then centrifuged $(1200 \times \mathrm{g}$ for $20 \mathrm{~min})$ at $4^{\circ} \mathrm{C}$. The reaction mixture for this test was $3.0 \mathrm{ml}$, contained $0.1 \mathrm{ml}$ filtered aliquot, $2.7 \mathrm{ml}$ of $0.1 \mathrm{M}$ phosphate buffer having $\mathrm{pH} 7.4$ and $0.2 \mathrm{ml}$ of $100 \mathrm{mM}$ DTNB. The yellow color of the mixture was developed and absorbance of the reaction mixture were determined by using spectrophotometer at $412 \mathrm{~nm}$ and expressed as $\mu \mathrm{M} \mathrm{GSH} / \mathrm{g}$ protein.

\subsubsection{Glutathione Peroxidase (GSH-Px) Activity}

The GSH-Px activity was assessed by the method of Mohandas et al., [62]. The reaction mixture for this test was consisted of $1.49 \mathrm{ml}$ of $0.1 \mathrm{M}$ phosphate buffer having $\mathrm{pH} 7.4,0.1 \mathrm{ml}$ of $1 \mathrm{mM}$ sodium azide, $0.05 \mathrm{ml}$ of 1 $\mathrm{IU} / \mathrm{ml}$ glutathione reductase, $0.05 \mathrm{ml}$ of $1 \mathrm{mM} \mathrm{GSH}, 0.1 \mathrm{ml}$ of $1 \mathrm{mM}$ EDTA, $0.1 \mathrm{ml}$ of $0.2 \mathrm{mM}$ NADPH, 0.01 $\mathrm{ml}$ of $0.25 \mathrm{mM} \mathrm{H}_{2} \mathrm{O}_{2}$ and $0.1 \mathrm{ml}$ of $10 \%$ brain homogenate. The changes in absorbance of the reaction mixture i.e., disappearance of $\mathrm{NADPH}$ at $25^{\circ} \mathrm{C}$ were determined by using spectrophotometer at $340 \mathrm{~nm}$ and expressed as nMNADPH oxidized/min/mg protein using a molar extinction coefficient of $6.22 \times 10^{3} \mathrm{M}^{-1} \mathrm{~cm}^{-1}$.

\subsubsection{Lipid Peroxidation (TBARS) Activity}

The TBARS activity was assessed by the method of Iqbal et al., [63]. The reaction mixture for this test was consisted of $0.58 \mathrm{ml}$ of $0.1 \mathrm{M}$ phosphate buffer having pH 7.4, $0.2 \mathrm{ml}$ of $100 \mathrm{mM}$ ascorbic acid, $0.02 \mathrm{ml}$ of $100 \mathrm{mM}$ ferric chloride and $0.2 \mathrm{ml}$ of $10 \%$ brain homogenate. The reaction mixture was incubated at $37^{\circ} \mathrm{C}$ in a shaking water bath for 1 hrs. Then $1.0 \mathrm{ml}$ of $10 \%$ TCA was added to stop the reaction. Following addition of $1.0 \mathrm{ml}$ $0.67 \%$ TBA, all the test tubes were boiled in a water-bath for $20 \mathrm{~min}$. Then the test tubes were shifted to crushed ice-bath before centrifuging $(2500 \times \mathrm{g}$ for $10 \mathrm{~min})$. The amount of TBARS formed in each of the samples was assessed by measuring optical density of the supernatant by using spectrophotometer at $535 \mathrm{~nm}$ against a reagent blank and expressed as nM TBARS $/ \mathrm{min} / \mathrm{mg}$ protein at $37^{\circ} \mathrm{C}$ using a molar extinction coefficient of $1.56 \times 10^{5}$ $\mathrm{M}^{-1} \mathrm{~cm}^{-1}$.

\subsubsection{Acetylcholinesterase (AChE) Activity}

The AChE activity was assessed by the method of Ellman et al., [64]. For this test, $25 \mu \mathrm{l}$ of $15 \mathrm{mM}$ ATCI, $75 \mu \mathrm{l}$ of $3 \mathrm{mM}$ DTNB and $75 \mu \mathrm{l}$ of $50 \mathrm{mM}$ Tris-HCl having $\mathrm{pH}$ 8.0, containing $0.1 \%$ BSA were added in the 96 well plates and incubated for $5 \mathrm{~min}$ at $25^{\circ} \mathrm{C}$. Then absorbance was determined by using spectrophotometer at $405 \mathrm{~nm}$. 
Any increase in the absorbance owing to the regular hydrolysis of the substrate was adjusted by subtracting the rate of the reaction before adding the enzyme. Then $25 \mu \mathrm{l}$ of $10 \%$ brain homogenates was added and the absorbance was determined again after incubation for $5 \mathrm{~min}$ at $25^{\circ} \mathrm{C}$ and expressed as $\mathrm{M} / \mathrm{min} / \mathrm{g}$ protein.

\subsection{Statistical Analysis}

All the results were expressed as mean \pm SEM, and were analyzed using a one-way analysis of variance (ANOVA). For behavioral studies Tukey's post hoc test were performed and in case of biochemical studies the least significant difference (LSD) was determined using post hoc testing for inter group comparisons at a probability level of $0.05 \%$ and $0.01 \%$. Statistical and graphical analyses were performed using SPSS 14.0 (Chicago, IL, USA) and MS Excel 2010 (Roselle, IL, USA). The results were considered as statistical significance at P < 0.05 with respect to disease control and control group.

\section{Results}

\subsection{Determination of Acute Toxicity}

During the observation period any behavioral, motor and neuronal functions change and mortality were not reported as well as the monitoring of skin, fur and eyes of the rats remained unchanged so the extracts were considered safe.

\subsection{Neuroprotective Effect of MEPA on ITL and RTL of Rats Using EPM Test}

EPM test was used to examine spatial long-term memory improving power of MEPA. The ITL was measured on $6^{\text {th }}$ and $13^{\text {th }}$ day and RTL was measured on $7^{\text {th }}$ and $14^{\text {th }}$ day respectively. The rat in all treatment groups except scopolamine-treated group showed decreased in RTL on $7^{\text {th }}$ and $14^{\text {th }}$ day compared to $6^{\text {th }}$ and $13^{\text {th }}$ day ITR of the same group given in Figure 1. In case of donepezil treated rats the values of RTL were markedly $(\mathrm{P}<0.05)$ decreased as compared to disease control and control group. Administration of MEPA markedly $(\mathrm{P}<0.05, \mathrm{P}<$ $0.01 ; \mathrm{P}<0.01$ ) decreased RTL of rats as compared to that of disease control and control group.

\subsection{Neuroprotective Effect of MEPA on TL and STL of Rats Using PA Test}

PA test was used to examine emotional long-term memory increasing action of MEPA. The TL was measured on $6^{\text {th }}$ and $13^{\text {th }}$ day and STL was measured on $7^{\text {th }}$ and $14^{\text {th }}$ day respectively. For all of the treatment groups except scopolamine-treated group presented significant increased in STL on $7^{\text {th }}$ and $14^{\text {th }}$ day compared to $6^{\text {th }}$ and $13^{\text {th }}$ day TL of the same group which was specified in Figure 2. In case of donepezil treated rats the values of STL was markedly $(\mathrm{P}<0.01$; $\mathrm{P}<0.05$, $\mathrm{P}<0.01)$ increased as compared to disease control and control group. The rats treated with MEPA significantly $(\mathrm{P}<0.05, \mathrm{P}<0.001$; $\mathrm{P}<0.05, \mathrm{P}<0.01)$ increased STL with respect to disease control and control group.

\subsection{Neuroprotective Effect of MEPA on DI of Rats Using NOR Test}

NOR test was used to determine the object recognition memory enhancing activity of MEPA. The DI for test session was measured on $7^{\text {th }}$ and $14^{\text {th }}$ day respectively. Administration of MEPA significantly $(\mathrm{P}<0.01, \mathrm{P}<$ 0.001; $\mathrm{P}<0.01$ ) increased the DI in rats as compared to that of disease control and control group. In fact, all of the treatment groups showed an increase in DI except scopolamine-treated group. The rats treated with donepezil possessed significantly ( $<<0.05 ; \mathrm{P}<0.05$, $\mathrm{P}<0.01$ ) increased in $\mathrm{DI}$ with respect to disease control and control group (Figure 3).

\subsection{Neuroprotective Effect of MEPA on EL, TSTQ and TSA of Rats Using MWM Test}

MWM was used to examine spatial learning and memory upgrading potentiality of MEPA. The EL and TSTQ for acquisition trial was measured on $7^{\text {th }}$ and $14^{\text {th }}$ day. The rat showed significantly decreased in the EL and increased in the TSTQ on respective days in all treatment groups except scopolamine treated group which was given in Figure 4 and Figure 5 respectively. The donepezil treated group possessed significantly $(\mathrm{P}<0.01)$ decreased in the EL and considerably ( $\mathrm{P}<0.05, \mathrm{P}<0.01$; $\mathrm{P}<0.05$ ) increased in the TSTQ comparable to disease 


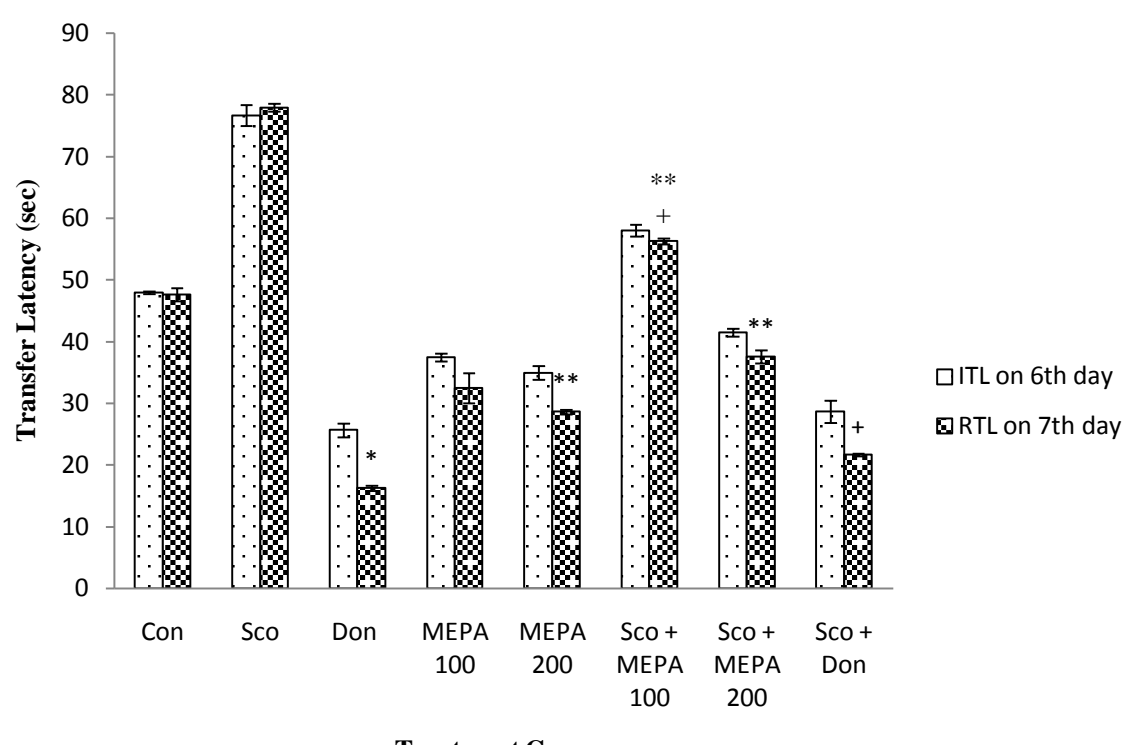

(a)

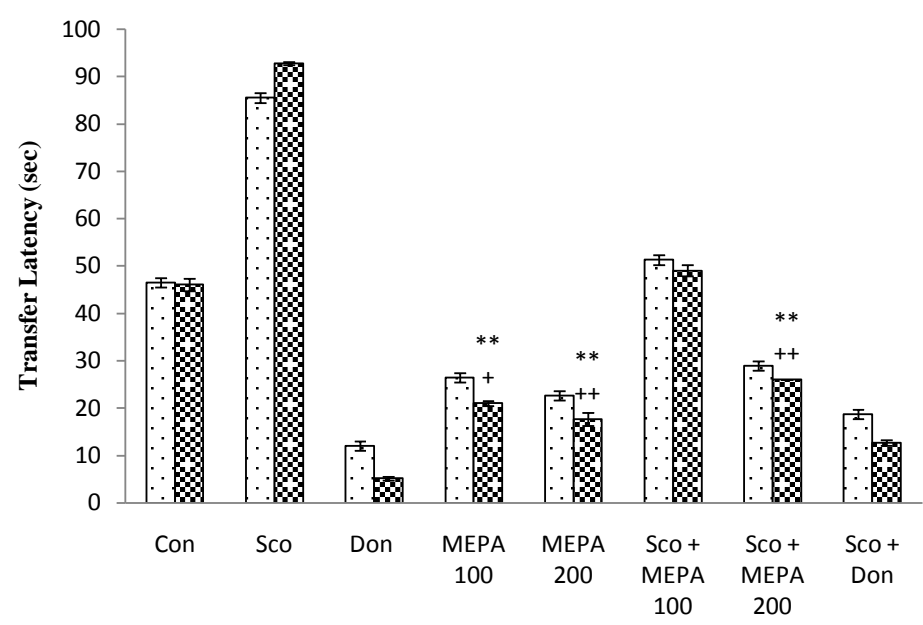

๑ITL on 13th day

RTL on 14th day

Treatment Groups

(b)

Figure 1. Neuroprotective effect of MEPA on ITL and RTL of rats using EPM test. Values expressed are mean \pm SEM ( $=6 /$ group). (a) ITL and RTL on $6^{\text {th }}$ and $7^{\text {th }}$ day respectively; (b) ITL and RTL on $13^{\text {th }}$ and $14^{\text {th }}$ day respectively. ${ }^{+} \mathrm{P}<0.05,{ }^{++} \mathrm{P}<0.01$ significant difference from the disease control group. ${ }^{*} \mathrm{P}<0.05,{ }^{* *} \mathrm{P}<0.01$ significant difference from the control group.

control and control group for acquisition trial. Administration of MEPA markedly ( $<<0.05, \mathrm{P}<0.01$; $\mathrm{P}<0.01$ ) decreased the EL and significantly ( $<<0.01, \mathrm{P}<0.001$; $\mathrm{P}<0.05, \mathrm{P}<0.01$ ) increased TSTQ in rats with respect to disease control and control group. Similar to acquisition trial for probe trial on $14^{\text {th }}$ day administration of MEPA markedly ( $\mathrm{P}<0.05, \mathrm{P}<0.01$; $\mathrm{P}<0.05, \mathrm{P}<0.01)$ increased TSTQ and significantly $(\mathrm{P}<0.05, \mathrm{P}<0.01$; $\mathrm{P}<0.05, \mathrm{P}<0.01$ ) increased TSA of rats as compared to that of disease control and control group, thus showed significant improvement of spatial learning and memory shown in Figure 6.

\subsection{Neuroprotective Effect of MEPA on Oxidative Status in Rat's Brain}

Brain antioxidant enzymes and malondialdehyde level was determined in rats brain tissue homogenates given in Table 2. The rat showed an increase in the activity of CAT, SOD, GSR GST, GSH, GSH-Px and decreased 


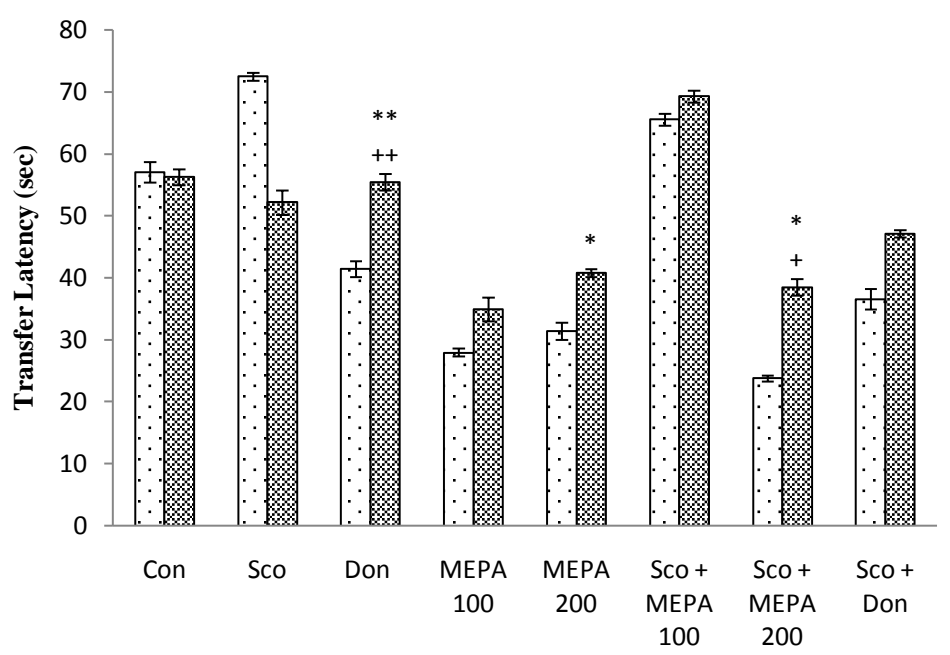

$\square T L$ on 6th day

응 on 7th day

Treatment Groups

(a)

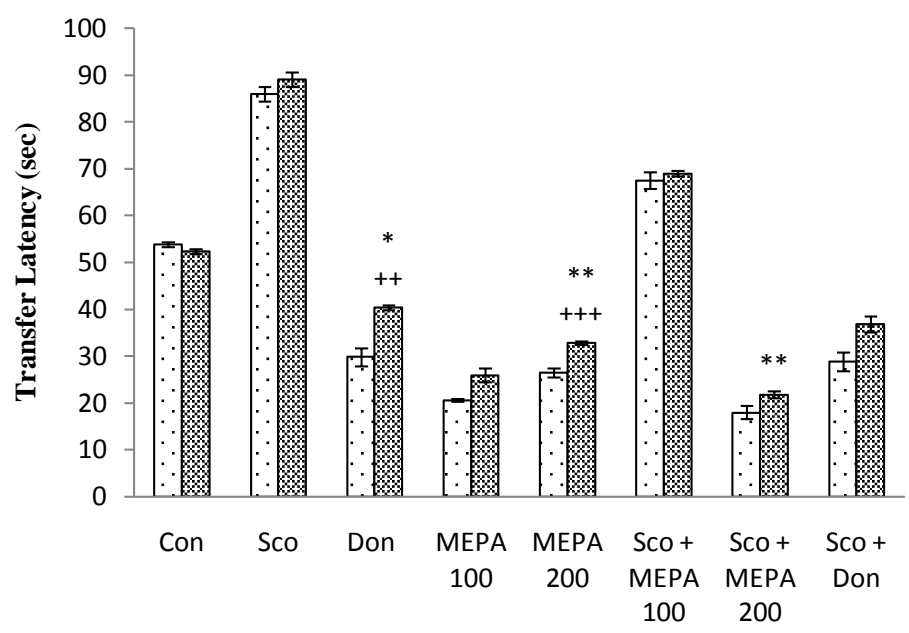

๑TL on 13th day

Tㄴ on 14th day

Treatment Groups

(b)

Figure 2. Neuroprotective effect of MEPA on TL and STL of rats using PA test. Values expressed are mean \pm SEM ( $n=6$ /group). (a) TL and STL on $6^{\text {th }}$ and $7^{\text {th }}$ day respectively; (b) TL and STL on $13^{\text {th }}$ and $14^{\text {th }}$ day respectively. ${ }^{+} \mathrm{P}<0.05,{ }^{++} \mathrm{P}<0.01,{ }^{+++} \mathrm{P}<0.001$ significant difference from the disease control group. ${ }^{*} \mathrm{P}<0.05,{ }^{* *} \mathrm{P}<0.01$ significant difference from the control group.

in the activity of TBARS in all groups except scopolamine treated group. Administration of MEPA considerably $(\mathrm{P}<0.05, \mathrm{P}<0.01, \mathrm{P}<0.001 ; \mathrm{P}<0.05, \mathrm{P}<0.01)$ increased the concentration of CAT, SOD, GSR, GST, GSH, GSH-Px and significantly $(\mathrm{P}<0.01$; $\mathrm{P}<0.01, \mathrm{P}<0.001)$ reduced TBARS to that of disease control group and control group. Donezepil administration considerably $(\mathrm{P}<0.05, \mathrm{P}<0.01$; $\mathrm{P}<0.05, \mathrm{P}<0.01, \mathrm{P}<0.001)$ increased the concentration of CAT, SOD, GSR, GST, GSH, GSH-Px and noticeably $(\mathrm{P}<0.01)$ decreased TBARS as compared to disease control and control group.

\subsection{Neuroprotective Effect of MEPA on AChE Activity in Rat's Brain}

The levels of AChE were measured in rat brain homogenates as a marker of central cholinergic status, which is compulsory in keeping typical cognitive functions. Scopolamine treatment meaningfully increased the brain AChE level compared to control group. Administration of MEPA significantly $(\mathrm{P}<0.01, \mathrm{P}<0.001$; $\mathrm{P}<0.05$, 


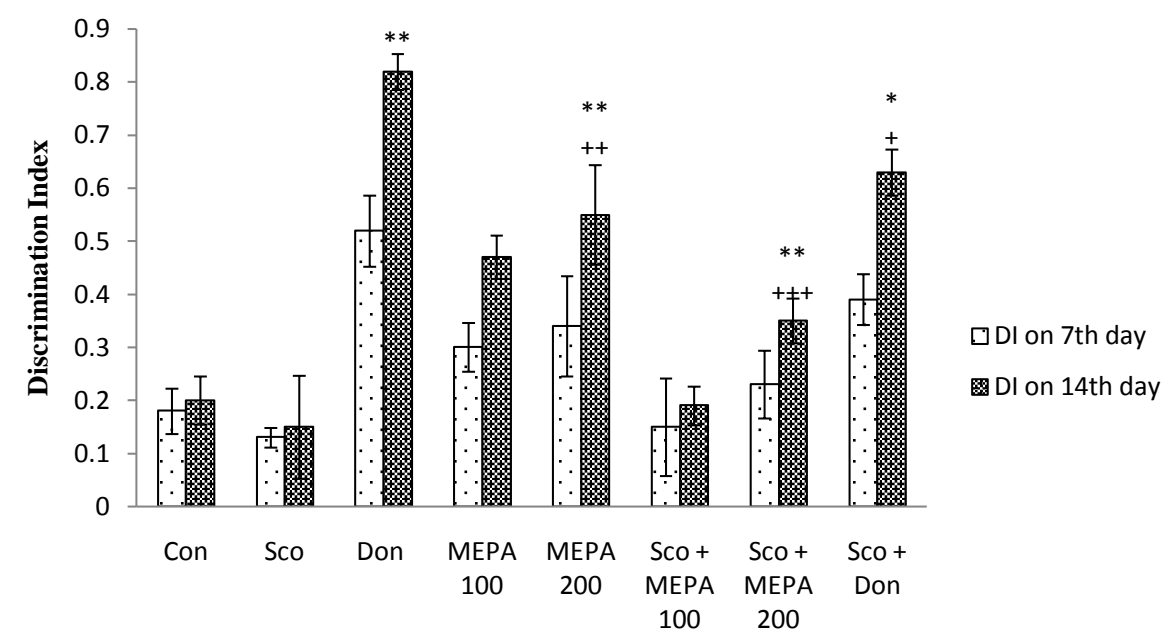

Treatment Groups

Figure 3. Neuroprotective effect of MEPA on DI of rat for test session using NOR test. Values expressed are mean \pm SEM ( $\mathrm{n}=6$ /group). ${ }^{+} \mathrm{P}<0.05,{ }^{++} \mathrm{P}<0.01,{ }^{+++} \mathrm{P}<0.001$ significant difference from the disease control group. ${ }^{*} \mathrm{P}<0.05,{ }^{* *} \mathrm{P}<0.01$ significant difference from the control group.

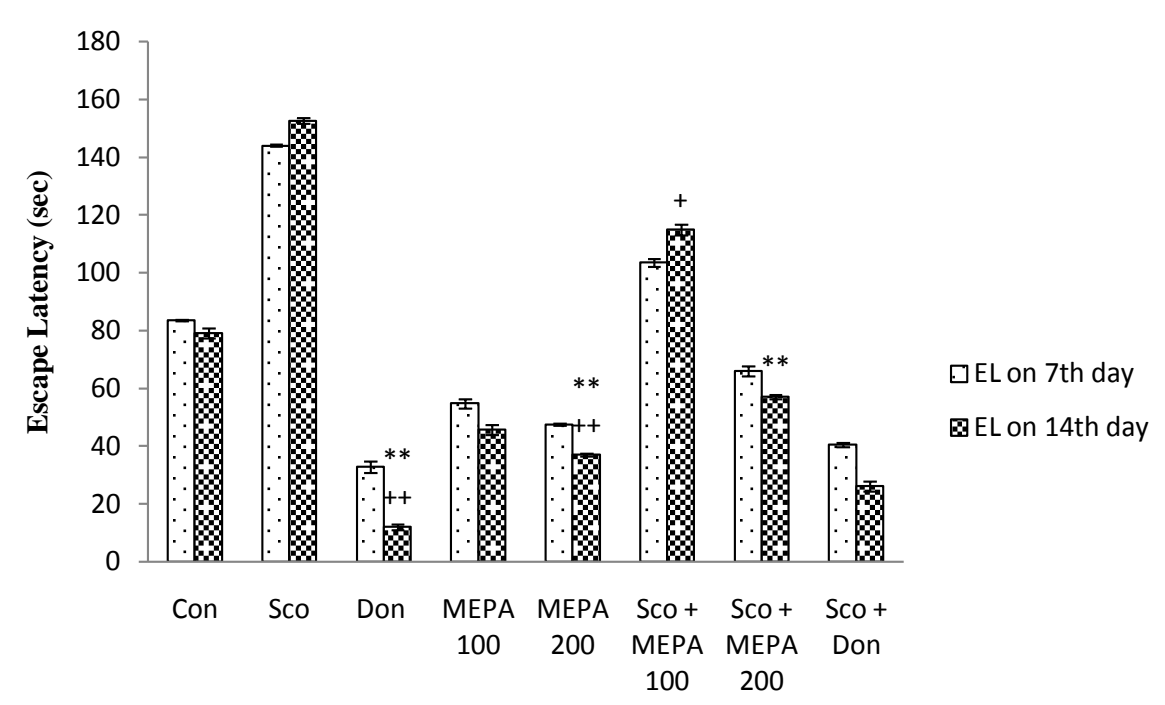

Treatment Groups

Figure 4. Neuroprotective Effect of MEPA on EL of rat for acquisition trial using MWM test. Values expressed are mean \pm SEM $(n=6 /$ group $) .{ }^{+} \mathrm{P}<0.05,{ }^{++} \mathrm{P}<0.01$ significant difference from the disease control group ${ }^{* *} \mathrm{P}<0.01$ significant difference from the control group.

$\mathrm{P}<0.01, \mathrm{P}<0.001)$ decreases the AChE activity in the brain tissue of rats as compared to disease control and control group. Standard drug, donepezil treatment significantly $(\mathrm{P}<0.01)$ inhibited the brain AChE level compared to their corresponding disease control and control group presented in Table 3.

\section{Discussion}

Medicinal plants are store house of phytochemicals for treatment of countless major and minor disease. In the treatment of the neurodegenerative particularly AD the phytoconstituents of medicinal plants play a crucial role as stated earlier [65]. The scopolamine-induced animal model of dementia and oxidative stress is widely used as 


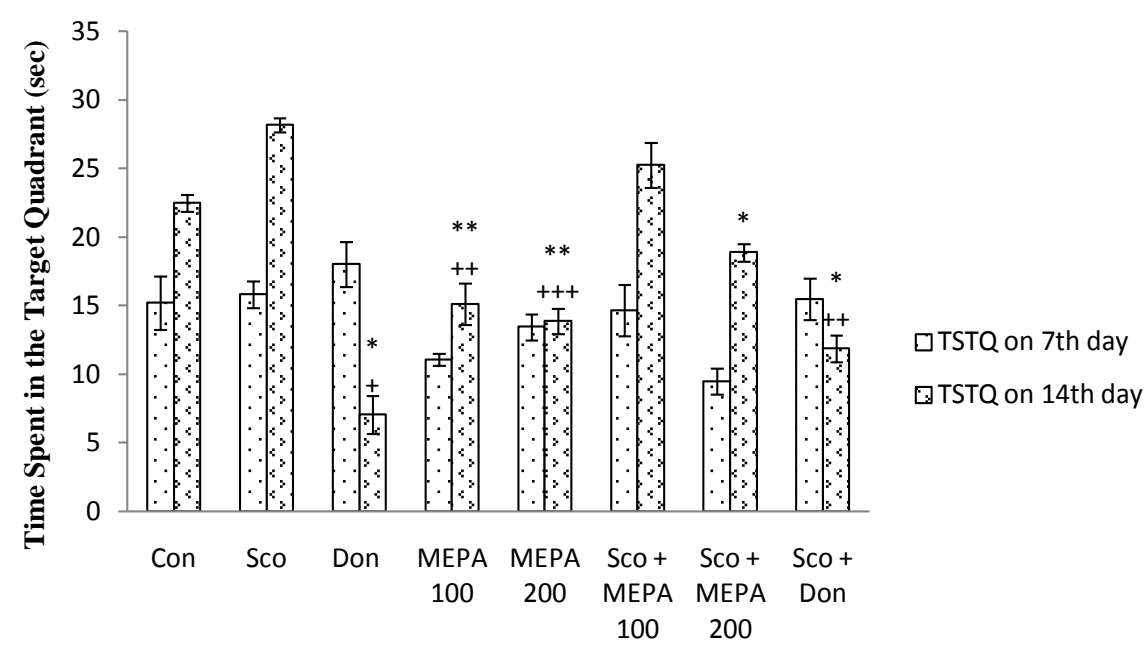

Treatment Groups

Figure 5. Neuroprotective effect of MEPA on TSTQ of rat for acquisition trial using MWM test. Values expressed are mean \pm SEM ( $n=6$ /group). ${ }^{+} \mathrm{P}<0.05,{ }^{++} \mathrm{P}<0.01,{ }^{+++} \mathrm{P}<$ 0.001 significant difference from the disease control group. ${ }^{*} \mathrm{P}<0.05,{ }^{* *} \mathrm{P}<0.01$ significant difference from the control group.

a primary screening test for the determination of anti-Alzheimer effect of unknown plants or drugs [66]. In this study, MEPA administration for $14^{\text {th }}$ days showed significant neuroprotective effect by improving various types of memory, learning, antioxidant enzymes and anti-acetylcholinesterase activity in rats. This is the first study showing neuroprotective activity of MEPA in rats by using various behavioral and biochemical studies.

Spatial long term memory is evaluated by EPM test in which the measured parameters were ITL and RTL. The time spent by the rat to move from the open arm to the closed arm in this test was recorded as ITL. After 24 hrs of ITL the retention of learned task was studied as RTL. In this test, a decrease in RTL on $7^{\text {th }}$ and $14^{\text {th }}$ day after the ILT on $6^{\text {th }}$ and $13^{\text {th }}$ day respectively indicated improvement of spatial long-term memory of rats as compared to disease control and control group. Swaroop et al., in the study on neuroprotective evaluation of leaf extract of Dalbergia sissoo in 3-nitropropionic acid induced neurotoxicity in rats similar findings were reported [67]. Emotional memory of rats after an aversive stimulus was evaluated by PA test in which the measured parameters were TL and STL. In this test an increase in STL on $7^{\text {th }}$ and $14^{\text {th }}$ day after the TL on $6^{\text {th }}$ and $13^{\text {th }}$ day respectively indicated improvement of learning and memory of rats as compared to disease control and control group. In the study on Elephantopus scaber in mice Sagar et al., also reported an increase in STL [68]. Recognition memory of rats is evaluated by NOR test in which the measured parameter is DI. In this test, an increase in DI on $7^{\text {th }}$ and $14^{\text {th }}$ day after the training session on $6^{\text {th }}$ and $13^{\text {th }}$ day respectively indicated improvement of recognition memory of rats as compared to disease control and control group. Equivalent consequences were reported by Wang et al., in the study of effects of Fructus akebiae on learning and memory impairment in a scopolamine-induced animal model of dementia [69]. Spatial learning and memory of rats was evaluated by MWM test in which the measured parameters were EL, TSTQ and TSA. In this test for acquisition trial a decrease in EL \& increase in TSTQ on $7^{\text {th }}$ and $14^{\text {th }}$ days and for probe trial an increase in TSTQ \& TSA on $14^{\text {th }}$ day indicated improvement of spatial learning and memory of rats as compared to disease control and control group. In the study on the effects of Loranthus parasiticus on scopolamine-induced memory impairment in mice almost same outcomes were reported by Weon et al., [39].

To shield cellular constituents from oxidative stress CAT and SOD has important roles. CAT is a very important enzyme in protecting the cell from oxidative damage by ROS. It converts damaging hydrogen peroxide to less-reactive water and molecular oxygen [70]. Superoxide is one of the main reactive oxygen species in the cell. SOD causes decomposition of superoxide $\left(\mathrm{O}^{2-}\right)$ radical into less-damaging hydrogen peroxide $\left(\mathrm{H}_{2} \mathrm{O}_{2}\right)$ and molecular oxygen $\left(\mathrm{O}_{2}\right)$. As a consequence, SOD serves a key antioxidant role [71]. Glutathione plays a key role in maintaining proper function and preventing oxidative stress in human cells by reacting with ROS such as free radicals, peroxides, lipid peroxides and heavy metals. GSR converts glutathione disulfide (GSSG) to reduced 


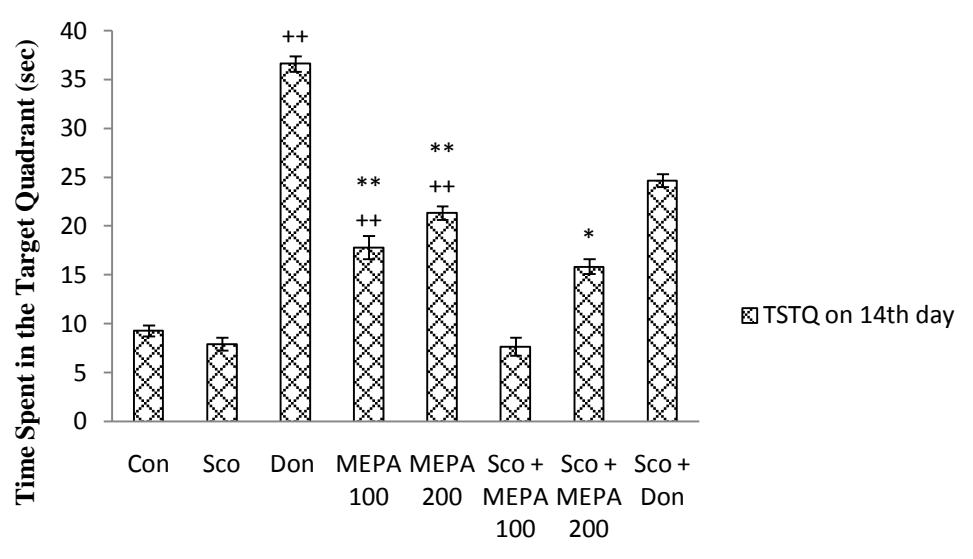

Treatment Groups

(a)

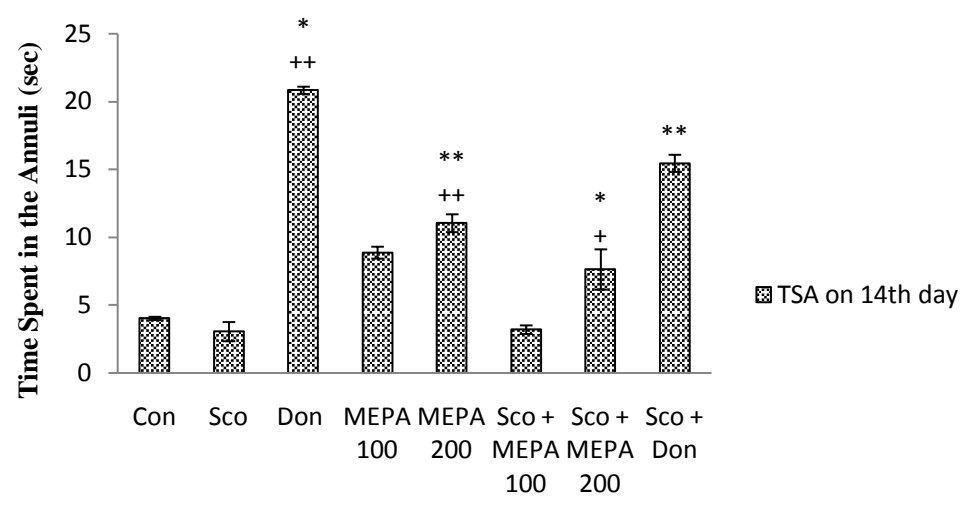

Treatment Groups

(b)

Figure 6. Neuroprotective effect of MEPA on TSTQ and TSA of rat for probe trial using MWM test. Values expressed are mean \pm SEM ( $\mathrm{n}=$ 6/group). (a) TSTQ on $14^{\text {th }}$ day; (b) TSA on $14^{\text {th }}$ day. ${ }^{+} \mathrm{P}<0.05,{ }^{++} \mathrm{P}<0.01$ significant difference from the disease control group. ${ }^{*} \mathrm{P}<0.05,{ }^{* *} \mathrm{P}<0.01$ significant difference from the control group.

Table 2. Neuroprotective Effect of MEPA on biochemical parameters of rat brain antioxidant defense system.

\begin{tabular}{|c|c|c|c|c|c|c|c|}
\hline Treatment & $\begin{array}{c}\text { CAT } \\
\text { (U/min) }\end{array}$ & $\begin{array}{l}\text { SOD }(\mathbf{U} / \mathbf{m g} \\
\text { protein) }\end{array}$ & $\begin{array}{c}\text { GSR } \\
\text { (nM/min/mg } \\
\text { protein) }\end{array}$ & $\begin{array}{c}\text { GST (nM/min/mg } \\
\text { protein) }\end{array}$ & $\begin{array}{c}\text { GSH }(\boldsymbol{\mu M} / \mathrm{g} \\
\text { protein) }\end{array}$ & $\begin{array}{c}\text { GSH-Px } \\
\text { (nM/min/mg } \\
\text { protein) }\end{array}$ & $\begin{array}{c}\text { TBARS } \\
\text { (nM/min/mg } \\
\text { protein) }\end{array}$ \\
\hline Con & $10.17 \pm 0.68$ & $9.57 \pm 0.22$ & $156.72 \pm 6.28$ & $115 \pm 1.42$ & $62.79 \pm 8.95$ & $37.92 \pm 3.85$ & $210.54 \pm 8.82$ \\
\hline Sco & $7.68 \pm 1.32$ & $8.05 \pm 1.54$ & $96.18 \pm 4.25$ & $76.64 \pm 5.75$ & $37.89 \pm 5.75$ & $18.09 \pm 1.75$ & $268.15 \pm 9.24$ \\
\hline Don & $18.32 \pm 0.47^{++* *}$ & $22.5 \pm 0.65$ & $286.68 \pm 3.89^{++* *}$ & $195.56 \pm 8.76^{+*}$ & $\begin{array}{l}125.78 \pm \\
10.74^{++* *}\end{array}$ & $93.48 \pm 1.02$ & $105.63 \pm 10.18^{++* *}$ \\
\hline MEPA 100 & $12.05 \pm 0.79$ & $13.03 \pm 1.21^{+*}$ & $195.17 \pm 6.81$ & $138.00 \pm 6.84$ & $78.93 \pm 7.49^{++*}$ & $48.63 \pm 2.89^{+}$ & $180.86 \pm 2.96$ \\
\hline MEPA 200 & $14.06 \pm 0.65^{++}$ & $16.75 \pm 1.07^{++* *}$ & $219 \pm 4.07$ & $156.76 \pm 7.69^{++* *}$ & $89.26 \pm 6.76^{++* *}$ & $68.08 \pm 1.13^{+* *}$ & $157.18 \pm 7.56^{++* * *}$ \\
\hline $\begin{array}{c}\text { Sco + MEPA } \\
100\end{array}$ & $9.54 \pm 0.46^{++*}$ & $8.95 \pm 1.18$ & $123.85 \pm 7.17$ & $93.95 \pm 4.94^{+}$ & $52.65 \pm 5.76$ & $26.58 \pm 5.84^{+*}$ & $229.49 \pm 5.15$ \\
\hline $\begin{array}{c}\text { Sco + MEPA } \\
200\end{array}$ & $10.95 \pm 1.23$ & $11.05 \pm 0.65^{+*}$ & $172 \pm 5.25^{++* *}$ & $128.09 \pm 5.57$ & $70.76 \pm 11.97$ & $41.28 \pm 0.95^{+++* *}$ & $195.48 \pm 6.09^{++* *}$ \\
\hline Sco + Don & $13.95 \pm 0.48^{+*}$ & $15.26 \pm 1.02^{++* *}$ & * $\quad 236.95 \pm 8.02$ & $178.25 \pm 10.97$ & $98.25 \pm 10.67^{* *}$ & $72.54 \pm 1.09^{++* * *}$ & * $\quad 136.28 \pm 7.65$ \\
\hline
\end{tabular}

The rats brain biochemical parameters are expressed as mean \pm SEM values ( $\mathrm{n}=6$ /group). ${ }^{+} \mathrm{P}<0.05,{ }^{++} \mathrm{P}<0.01,{ }^{+++} \mathrm{P}<0.001$ significant difference from the disease control group. ${ }^{*} \mathrm{P}<0.05,{ }^{* *} \mathrm{P}<0.01,{ }^{* * *} \mathrm{P}<0.001$ significant difference from the control group. 
Table 3. Neuroprotective Effect of MEPA on AChE activity in rat brain.

\begin{tabular}{|c|c|}
\hline Treatment & AChE (M/min/g protein) \\
\hline Con & $0.182 \pm 0.003$ \\
\hline Sco & $0.245 \pm 0.002$ \\
\hline Don & $0.045 \pm 0.001^{++* *}$ \\
\hline MEPA 100 & $0.134 \pm 0.005^{* *}$ \\
\hline MEPA 200 & $0.115 \pm 0.005^{++* *}$ \\
\hline Sco + MEPA 100 & $0.201 \pm 0.003^{*}$ \\
\hline Sco + MEPA 200 & $0.149 \pm 0.004^{+++* * *}$ \\
\hline Sco + Don & $0.087 \pm 0.030$ \\
\hline
\end{tabular}

glutathione (GSH) which in turn assist to GSH-Px in the reduction of $\mathrm{H}_{2} \mathrm{O}_{2}$ [72]. GST catalyzes the nucleophilic addition of glutathione (GSH) to substrates that have electrophilic functional groups. It mainly participates in detoxification of endo- and exogeneous alkylating agents thereby preventing their interaction with essential cellular components such as proteins and nucleic acids [73]. GSH exerts antioxidant action by donating reducing equivalent to ROS as well as other unstable molecules. By donating an electron glutathione becomes reactive, but easily reacts with another molecule of glutathione to generate glutathione disulfide (GSSG) [74]. The main biological role of GSH-Px is to protect the organism from oxidative damage of $\mathrm{H}_{2} \mathrm{O}_{2}$. It converts lipid hydroperoxides to their corresponding alcohols and to reduce free $\mathrm{H}_{2} \mathrm{O}_{2}$ to $\mathrm{H}_{2} \mathrm{O}$ (water) [75]. The central nervous system (CNS) is highly sensitive to oxidative stress due to high levels of polyunsaturated fatty acids (PUFAs), high oxygen consumption, high levels of redox transition metals and poor antioxidative defense of the brain as specified previous. Several researchers in various brain regions showed that the CNS is the major targets of lipid peroxidation process [76]. Indeed, in the pathogenesis of neurodegenerative disorder specially AD free radicalmediated lipid peroxidation serve as triggers [77]. In the present study, rats after scopolamine treatment showed a significant decrease of brain antioxidant enzymes such as CAT, SOD, GSR, GST GSH, GSH-Px and increase in the brain levels of TBARS, which is the measure of lipid peroxidation and free radical generation. The current study showed that administration of MEPA significantly increases the level of brain antioxidant enzymes and decrease in the levels of TBARS. Khan showed that administration of methanolic extracts of Launaea procumbens in rats increases rats brain antioxidant enzymes and cognitive performance [78]. Excitatory neurotransmitter, ACh is more imperious for neuronal communication. AChE enzyme is responsible for degradation of ACh and the level of this degradative enzyme is higher in Alzheimer patients [79]. The results of this study exposed that AChE activity was increased in scopolamine injected group and significantly decreased in the MEPA groups. In the study on effects of Persicaria flaccida on brain antioxidant markers, cognitive performance and AChE activity of rats by Uddin et al., showed that this plant extracts has potential nootropic activity [80].

Our results suggested that administration of MEPA produced superior neuroprotective effect in rats as compared to disease control and control group. The above behavioral and biochemical results suggest that MEPA has the ability to alter the development and progression of AD.

\section{Conclusion}

The present study clearly demonstrates that MEPA fruits significantly attenuate scopolamine-induced dementia and oxidative stress by improving the learning, memory, antioxidant potentiality and anti-acetylcholinesterase activity. Therefore, this fruit extract can be a potential novel therapeutic strategy for controlling neurodegenerative dementia especially AD. Yet, advance studies are needed to characterize the active compound(s) and expose the possible mechanism of action. 


\section{Acknowledgements}

The authors wish to thank the Department of Pharmacy, Southeast University, Dhaka, Bangladesh for providing financial support and research facilities.

\section{Ethical Approval}

The study protocol was approved by the ethics committee of the Department of Pharmacy, Southeast University, Dhaka, Bangladesh. The care and use of the animals were followed in accordance with the principles of laboratory animal care (NIH publication No. 85-23, revised 1985).

\section{Author's Contributions}

This work was carried out in collaboration among all authors. MSU, AAM, MSA and MA performed the laboratory experiments and prepare the manuscript. AAN, MSH and JS helped for statistical analysis and interpretation of data. MJU revised the final manuscript. MA designed and supervised the study. All authors read and approved the final manuscript.

\section{Conflict of Interests}

The authors have declared no conflict of interests with the content of the article.

\section{References}

[1] Sternberg, R.J. and Pretz, J.E. (2005) Cognition and Intelligence: Identifying the Mechanisms of the Mind. Cambridge University Press, New York.

[2] Selnes, O.A. and Vinters, H.V. (2006) Vascular Cognitive Impairment. Nature Clinical Practice Neurology, 2, 538547. http://dx.doi.org/10.1038/ncpneuro0294

[3] Sosa, A., Albanese, E., Stephan, B.C.M., Dewey, M., Acosta, D., Ferri, C.P., et al. (2012) Prevalence, Distribution, and Impact of Mild Cognitive Impairment in Latin America, China, and India: A 10/66 Population-Based Study. PLoS Medicine, 9, 1-11. http://dx.doi.org/10.1371/journal.pmed.1001170

[4] Querfurth, H.W. and LaFerla, F.M. (2010) Alzheimer’s Disease. New England Journal of Medicine, 362, 329-344. http://dx.doi.org/10.1056/NEJMra0909142

[5] Wimo, A., Winblad, B., Aguero-Torres, H. and von Strauss, E. (2003) The Magnitude of Dementia Occurrence in the World. Alzheimer Disease \& Associated Disorders, 17, 63-67. http://dx.doi.org/10.1097/00002093-200304000-00002

[6] Asaduzzaman, M., Uddin, M.J., Kader, M.A., Alam, A.H.M.K., Rahman, A.A. and Rashid, M. (2014) In Vitro Acetylcholinesterase Inhibitory Activity and the Antioxidant Properties of Aegle marmelos Leaf Extract: Implications for the Treatment of Alzheimer's Disease. Psychogeriatrics, 14, 1-10. http://dx.doi.org/10.1111/psyg.12031

[7] Chang, Y.T., Chang, W.N., Tsai, N.W., Huang, C.C., Kung, C.T. and Su, Y.J. (2014) The Roles of Biomarkers of Oxidative Stress and Antioxidant in Alzheimer's Disease: A Systematic Review. BioMed Research International, 2014, 1-11. http://dx.doi.org/10.1155/2014/182303

[8] Oh, J.H., Choi, B.J., Chang, M.S. and Park, S.K. (2009) Nelumbo nucifera Semen Extract Improves Memory in Rats with Scopolamine-Induced Amnesia through the Induction of Choline Acetyltransferase Expression. Neuroscience Letters, 461, 41-44. http://dx.doi.org/10.1016/j.neulet.2009.05.045

[9] Fan, Y., Hu, J., Li, J., Yang, Z., Xin, X., Wang, J., et al. (2005) Effect of Acidic Oligosaccharide Sugar Chain on Scopolamine-Induced Memory Impairment in Rats and Its Related Mechanisms. Neuroscience Letters, 374, 222-226. http://dx.doi.org/10.1016/j.neulet.2004.10.063

[10] El-Sherbiny, D.A., Khalifa, A.E., Attia, A.S. and Eldenshary, E.S. (2003) Hypericum perforatum Extract Demonstrates Antioxidant Properties against Elevated Rat Brain Oxidative Status Induced by Amnestic Dose of Scopolamine. Pharmacology Biochemistry and Behavior, 76, 525-533. http://dx.doi.org/10.1016/j.pbb.2003.09.014

[11] Jeong, E.J., Lee, K.Y., Kim, S.H., Sung, S.H. and Kim, Y.C. (2008) Cognitive-Enhancing and Antioxidant Activities of Iridoid Glycosides from Scrophularia buergeriana in Scopolamine-Treated Mice. European Journal of Pharmacology, 588, 78-84. http://dx.doi.org/10.1016/j.ejphar.2008.04.015

[12] Sultana, R. and Butterfield, D.A. (2010) Role of Oxidative Stress in the Progression of Alzheimer's Disease. Journal of Alzheimer's Disease, 19, 341-353.

[13] Hossain, M.S., Asaduzzaman, M., Uddin, M.S., Noor, M.A.A., Rahman, M.A. and Munira, M.S. (2015) Investigation 
of the in Vitro Antioxidant and Cytotoxic Activities of Xanthosoma sagittifolium Leaf. Indo American Journal of Pharmaceutical Research, 5, 3300.

[14] Kuhla, B., Haase, C., Flach, K., Luth, H.J., Arendt, T. and Munch, G. (2007) Effect of Pseudophosphorylation and Cross-Linking by Lipid Peroxidation and Advanced Glycation End Product Precursors on Tau Aggregation and Filament Formation. Journal of Biological Chemistry, 282, 6984-6991. http://dx.doi.org/10.1074/jbc.M609521200

[15] Zimmerman, G. and Soreq, H. (2006) Termination and Beyond: Acetylcholinesterase as a Modulator of Synaptic Transmission. Cell and Tissue Research, 326, 655-669. http://dx.doi.org/10.1007/s00441-006-0239-8

[16] Lane, R.M., Potkin, S.G. and Enz, A. (2006) Targeting Acetylcholinesterase and Butyrylcholinesterase in Dementia. International Journal of Neuropsychopharmacology, 9, 101-124. http://dx.doi.org/10.1017/S1461145705005833

[17] Zawia, N.H., Lahiri, D.K. and Cardozo-Pelaez, F. (2009) Epigenetics, Oxidative Stress, and Alzheimer Disease. Free Radical Biology \& Medicine, 46, 1241-1249. http://dx.doi.org/10.1016/j.freeradbiomed.2009.02.006

[18] Jayakumar, T., Thomas, P.A. and Geraldine, P. (2007) Protective Effect of an Extract of the Oyster Mushroom, Pleurotus ostreatus, on Antioxidants of Major Organs of Aged Rats. Experimental Gerontology, 42, 183-191. http://dx.doi.org/10.1016/j.exger.2006.10.006

[19] Gilgun-Sherki, V., Melamed, E. and Offen, D. (2001) Oxidative Stress Induced-Neurodegenerative Diseases: The Need for Antioxidants That Penetrate the Blood Brain Barrier. Neuropharmacology, 40, 959-975. http://dx.doi.org/10.1016/S0028-3908(01)00019-3

[20] Uttara, B., Singh, A.V., Zamboni, P. and Mahajan, R.T. (2009) Oxidative Stress and Neurodegenerative Diseases: A Review of Upstream and Downstream Antioxidant Therapeutic Options. Current Neuropharmacology, 7, 65-74. http://dx.doi.org/10.2174/157015909787602823

[21] Sharma, J., Chawla, R., Kumar, R., Sharma, A., Sharma, R.K. and Arora, R. (2013) Camellia sinensis as a Safe Neuroprotective Radiation Counter Measure Agent. International Journal of Pharmaceutical Science Invention, 2, 26-33.

[22] Duraipandiyan, V., Ayyanar, M. and Ignacimuthu, S. (2006) Antimicrobial Activity of Some Ethnomedicinal Plants Used by Paliyar Tribe from Tamil Nadu, India. BMC Complementary and Alternative Medicine, 6, 35. http://dx.doi.org/10.1186/1472-6882-6-35

[23] Jamison, D.T., Breman, J.G. and Meashametal, A.R. (2006) Complementary and Alternative Medicine, in Disease Control Priorities in Developing Countries. World Bank, Washington DC.

[24] Annonymus (2014) Traditional Medicine. https://en.wikipedia.org/wiki/Traditional_medicine

[25] Oken, B.S., Storzbach, D.M. and Kaye, J.A. (1995) The Efficacy of Ginkgo biloba on Cognitive Function in Alzheimer Disease. Archives of Neurology, 55, 1409-14015. http://dx.doi.org/10.1001/archneur.55.11.1409

[26] Goswami, S., Saoji, A., Kumar, N., Thawani, V., Tiwari, M. and Thawani, M. (2011) Effect of Bacopa monnierion Cognitive Functions in Alzheimer's Disease Patients. International Journal of Collaborative Research on Internal Medicine \& Public Health, 3, 285-293.

[27] Skolnick, A.A. (1997) Old Chinese Herbal Medicine Used for Fever Yields Possible New Alzheimer Disease Therapy. Journal of the American Medical Association, 277, 776. http://dx.doi.org/10.1001/jama.1997.03540340010004

[28] Habib, M.R., Rahman, M.M., Mannan, A., Zulfiker, A.H.M., Uddin, M.E. and Sayeed, M.A. (2011) Evaluation of Antioxidant, Cytotoxic, Antibacterial Potential and Phytochemical Screening of Chloroform Extract of Phyllanthus acidus. International Journal of Applied Biology and Pharmaceutical Technology, 2, 420-427.

[29] Padmapriya, N. and Poonguzhali, T.V. (2015) Antibacterial and Antioxidant Potential of the Acetone Extract of the Fruit of Phyllanthus acidus L. International Journal of Current Research, 17, E64-E72.

[30] Annonymus. Phyllanthus acidus. http://www.worldagroforestry.org/treedb/AFTPDFS/Phyllanthus_acidus.PDF

[31] Devi, S.S. and Paul, S.B. (2011) An Overview on Cicca acida (Phyllanthus acidus). Assam University Journal of Science \& Technology: Biological and Environmental Sciences, 7, 156-160.

[32] Catapan, E., Otuki, M.F., Viana, A.M., Yunes, R.A., Bresciani, L.F., Ferreira, J., et al. (2000) Pharmacological Activity and Chemical Composition of Callus Cultures Extracts from Selected Species of Phyllanthus. Pharmazie, 55, 945946.

[33] Shilali, K., Ramachandra, Y.L., Rajesh, K.P. and Swamy, B.E.K. (2014) Assessing the Antioxidant Potential of Phyllanthus acidus Bark Extracts. International Journal of Pharmacy and Pharmaceutical Sciences, 6, 522-531.

[34] Anjaria, J., Parabia, M., Bhatt, G. and Heals, K.R.N.A. (2002) Glossary of Selected Indigenous Medicinal Plants of India. Sristi Innovations, Ahmedabad.

[35] Lemmens, R.H., Bunyapraphatsara, M.J. and Padua de, L.S.N. (1999) Plant Resources of South-East Asia, Medicinal and Poisonous Plants. Prosea Foundation, Bogor.

[36] Unander, D.W., Webster, D.W. and Blumberg, B.S. (1990) Record of Usage or Assays in Phyllanthus (Euphorbiaceae) 
I. Subgenera Isocladus, Kirganelia, Cicca and Emblica. Journal of Ethnopharmacology, 30, 233-264. http://dx.doi.org/10.1016/0378-8741(90)90105-3

[37] Moniruzzaman, M., Asaduzzaman, M., Hossain, M.S., Sarker, J., Rahman S.M.A. and Rashid, M. (2015) In Vitro Antioxidant and Cholinesterase Inhibitory Activities of Methanolic Fruit Extract of Phyllanthus acidus. BMC Complementary and Alternative Medicine, 15, 403. http://dx.doi.org/10.1186/s12906-015-0930-y

[38] National Research Council (2011) Guide for the Care and Use of Laboratory Animals. National Academies Press, Washington DC.

[39] Weon, J.B., Lee, J., Eom, M.R., Jung, Y.S. and Ma, C.J. (2014) The Effects of Loranthus parasiticus on Scopolamine-Induced Memory Impairment in Mice. Evidence-Based Complementary and Alternative Medicine, 2014, Article ID: 860180. http://dx.doi.org/10.1155/2014/860180

[40] Jissa, G., Sai-Sailesh, K. and Mukkadan, J.K. (2014) Oral Administration of Nutmeg on Memory Boosting and Regaining in Wistar Albino Rats. Bali Medical Journal, 3, 3-10. http://dx.doi.org/10.15562/bmj.v3i1.61

[41] Saha, S. and Verma, R.J. (2015) Antioxidant Activity of Polyphenolic Extract of Phyllanthus emblica against Lead Acetate Induced Oxidative Stress. Toxicology and Environmental Health Sciences, 7, 82-90. http://dx.doi.org/10.1007/s13530-015-0224-2

[42] Organisation for Economic cooperation and Development (OECD) (2002) OECD Guidelines for the Testing of Chemicals: Acute Oral Toxicity—Acute Toxic Class Method. Paris, OECD. http://www.oecd-ilibrary.org/docserver/download/9742301e.pdf?ex

[43] Reddy, D.S. and Kulkarni, S.K. (1998) Possible Role of Nitric Oxide in the Nootropic and Antiamnesic Effects of Neurosteroids on Aging- and Dizocilpine-Induced Learning Impairment. Brain Research, 799, 215-229. http://dx.doi.org/10.1016/S0006-8993(98)00419-3

[44] Hlinak, Z. and Krejci, I. (2002) MK-801 Induced Amnesia for the Elevated Plus-Maze in Mice. Behavioural Brain Research, 131, 221-225. http://dx.doi.org/10.1016/S0166-4328(01)00347-3

[45] Kumar, S., Maheshwari, K.K. and Singh, V. (2009) Protective Effects of Punica granatum Seeds Extract against Aging and Scopolamine Induced Cognitive Impairments in Mice. African Journal of Traditional, Complementary and Alternative Medicines, 6, 1. http://www.ncbi.nlm.nih.gov/pubmed/20162041

[46] Ozkay U.D., Can, O.D., Ozkay, Y. and Ozturk, Y. (2012) Effect of Benzothiazole/Piperazine Derivatives on Intracerebroventricular Streptozotocin-Induced Cognitive Deficits. Pharmacological Reports, 64, 834-847. http://dx.doi.org/10.1016/S1734-1140(12)70878-2

[47] Ogren, S.O., Stone, W.S. and Altman, H.J. (1987) Evidence for a Functional Interaction between Serotonergic and Cholinergic Mechanisms in Memory Retrieval. Behavioral and Neural Biology, 48, 49-62. http://dx.doi.org/10.1016/S0163-1047(87)90574-7

[48] Van der Staay, F.J., Schuurman, T., van Reenen, C.G. and Korte, S.M. (2009) Emotional Reactivity and Cognitive Performance in Aversively Motivated Tasks: A Comparison between Four Rat Strains. Behavioral and Brain Functions, 5, 50. http://dx.doi.org/10.1016/S0163-1047(87)90574-7

[49] Weon, J.B., Yun, B.R., Lee, J., Eom, M.R., Kim, J.S., Lee, H.E., et al. (2013) The Ameliorating Effect of Steamed and Fermented Codonopsis lanceolata on Scopolamine Induced Memory Impairment in Mice. Evidence-Based Complementary and Alternative Medicine, 2013, 2-3. http://www.hindawi.com/journals/ecam/2013/464576/

[50] Morris, R. (1984) Developments of a Water-Maze Procedure for Studying Spatial Learning in the Rat. Journal of Neuroscience Methods, 11, 47-60. http://dx.doi.org/10.1016/0165-0270(84)90007-4

[51] Antunes, M. and Biala, G. (2012) The Novel Objects Recognition Memory: Neurobiology, Test Procedure, and Its Modifications. Cognitive Processing, 13, 93-110. http://dx.doi.org/10.1007/s10339-011-0430-z

[52] Ennaceur, A., Neave, N. and Aggleton, J.P. (1997) Spontaneous Object Recognition and Object Location Memory in Rats: The Effects of Lesions in the Cingulate Cortices, the Medial Prefrontal Cortex, the Cingulum Bundle and the Fornix. Experimental Brain Research, 113, 509-519. http://dx.doi.org/10.1007/PL00005603

[53] Dhingra, D. and Kumar, V. (2012) Memory-Enhancing Activity of Palmatine in Mice Using Elevated Plus Maze and Morris Water Maze. Advances in Pharmacological Sciences, 2012, Article ID: 357368. http://dx.doi.org/10.1155/2012/357368

[54] Taati, M., Alirezaei, M., Moshkatalsadat, M.H., Rasoulian, B., Moghadasi, M. and Sheikhzadeh, F. (2011) Protective Effects of Ziziphus jujube Fruit Extract against Ethanol-Induced Hippocampal Oxidative Stress and Spatial Memory Impairment in Rats. Journal of Medicinal Plants Research, 5, 915-921.

[55] Blokland, A., Geraerts, E. and Been, M.A. (2004) Detailed Analysis of Rat's Spatial Memory in a Probe Trial of a Morris Task. Behavioural Brain Research, 154, 71-75. http://dx.doi.org/10.1016/j.bbr.2004.01.022

[56] Das, A., Dikshit, M. and Nath, C. (2005) Role of Molecular Isoforms of Acetylcholinesterase in Learning and Memory 
Functions. Pharmacology Biochemistry \& Behavior, 81, 89-99. http://dx.doi.org/10.1016/j.pbb.2005.02.006

[57] Chance, B. and Maehly, A.C. (1955) Assay of Catalase and Peroxidases. Methods in Enzymology, 11, 764-775. http://dx.doi.org/10.1016/S0076-6879(55)02300-8

[58] Kakkar, P., Das, B. and Viswanathan, P.N.A. (1984) Modified Spectrophotometric Assay of Superoxide Dismutase. Indian Journal of Biochemistry and Biophysics, 21, 130-132.

[59] Carlberg, I. and Mannervik, E.B. (1975) Glutathione Level in Rat Brain. Journal of Biological Chemistry, 250, 44754480.

[60] Habig, W.H., Pabst, M.J. and Jakoby, W.B. (1974) Glutathione-S-Transferases: The First Enzymatic Step in Mercapturic Acid Formation. Journal of Biological Chemistry, 249, 7130-7139.

[61] Jollow, D.J., Mitchell, J.R., Zampaglione, N. and Gillete, J.R. (1974) Bromobenzene Induced Liver Necrosis, Protective Role of Glutathione and Evidence for 3, 4-Bromobenzene Oxide as a Hepatotoxic Metabolite. Pharmacology, 11, 151-169. http://dx.doi.org/10.1159/000136485

[62] Mohandas, J., Marshal, J.J., Duggin, G.G., Horvath, J.S. and Tiller, D.J. (1984) Differential Distribution of Glutathione and Glutathione-Related Enzymes in Rabbit Kidney: Possible Implications in Analgesic Nephropathy. Biochemical Pharmacology, 33, 1801-1807. http://dx.doi.org/10.1016/0006-2952(84)90353-8

[63] Iqbal, M., Sharma, M.D., Zadeh, H.R., Hasan, N., Abdulla, M. and Athar, M. (1996) Glutathione Metabolizing Enzymes and Oxidative Stress in Ferric Nitrilotriacetate (Fe-NTA) Mediated Hepatic Injury. Redox Report, 2, 385-391.

[64] Ellman, G.L., Courtney, K.D., Andres, V. and Featherstone, R.M. (1996) A New and Rapid Colorimetric Determination of Acetylcholinesterase Activity. Biochemical Pharmacology, 7, 88-95. http://dx.doi.org/10.1016/0006-2952(61)90145-9

[65] Kumar, G.P. and Khanum F. (2012) Neuroprotective Potential of Phytochemicals. Pharmacognosy Reviews, 6, 81-90. http://dx.doi.org/10.4103/0973-7847.99898

[66] Sattayasai, J., Chaonapan, P., Arkaravichie, T., Soi-ampornkul, R., Junnu, S., Charoensilp, P., et al. (2013) Protective Effects of Mangosteen Extract on $\mathrm{H}_{2} \mathrm{O}_{2}$-Induced Cytotoxicity in SK-N-SH Cells And Scopolamine-Induced Memory Impairment in Mice. PLOS ONE, 8, e85053. http://dx.doi.org/10.1371/journal.pone.0085053

[67] Swaroop, T.V.S.S., Banerjee, S. and Handral, M. (2014) Neuroprotective Evaluation of Leaf Extract of Dalbergia sissoo in 3-Nitropropionic Acid Induced Neurotoxicity in Rats. International Journal of Pharmaceutical Sciences and Drug Research, 6, 41-47.

[68] Sahoo, H.B., Mandal, P.K., Bhattamisra, S.K., Bhaiji, A. and Sagar, R. (2014) A New Weapon for Memory Power: Elephantopus scaber (Linn.). International Journal of Nutrition, Pharmacology, Neurological Diseases, 4, 64-67. http://dx.doi.org/10.4103/2231-0738.124616

[69] Wang, J., Wang, X., Lv, B., Yuan, W., Feng, Z. and Weidong, M.I. (2014) Effects of Fructus akebiae on Learning and Memory Impairment in a Scopolamine-Induced Animal Model of Dementia. Experimental and Therapeutic Medicine, 8, 671-675. http://dx.doi.org/10.3892/etm.2014.1775

[70] Celik, V.K., Ersan, E., Ersan, S., Bakır, S. and Dogan, O. (2013) Plasma Catalase, Glutathione-S-Transferase and Total Antioxidant Activity Levels of Children with Attention Deficit and Hyperactivity Disorder. Advances in Bioscience and Biotechnology, 4, 183-187. http://dx.doi.org/10.4236/abb.2013.42026

[71] Ansari, M.A. and Scheff, S.W. (2010) Oxidative Stress in the Progression of Alzheimer Disease in the Frontal Cortex. Journal of Neuropathology \& Experimental Neurology, 69, 155-167. http://dx.doi.org/10.1097/NEN.0b013e3181cb5af4

[72] Fang, Y.Z., Yang, S. and Wu, G. (2000) Free Radicals, Antioxidants, and Nutrition. Nutrition. 18, 872-879. http://dx.doi.org/10.1016/S0899-9007(02)00916-4

[73] Hayes, J.D., Flanagan, J.U. and Jowsey, I.R. (2005) Glutathione Transferases. Annual Review of Pharmacology and Toxicology, 45, 51-88. http://dx.doi.org/10.1146/annurev.pharmtox.45.120403.095857

[74] Yadav, P., Sarkar, S. and Bhatnagar, D. (1997) Action of Capparis deciduas against Alloxan-Induced Oxidative Stress and Diabetes in Rat Tissues. Pharmacological Research, 36, 221-228. http://dx.doi.org/10.1006/phrs.1997.0222

[75] Maritim, A.C., Sanders, R.A. and Watkins, J.B. (2003) Effects of $\alpha$-Lipoic Acid on Biomarkers of Oxidative Stress in Streptozotocin-Induced Diabetic Rats. Journal of Nutritional Biochemistry, 14, 288-294. http://dx.doi.org/10.1016/S0955-2863(03)00036-6

[76] Sultana, R., Perluigi, M. and Butterfield, D.A. (2013) Lipid Peroxidation Triggers Neurodegeneration: A Redox Proteomics View into the Alzheimer Disease Brain. Free Radical Biology and Medicine, 62, 157-169. http://dx.doi.org/10.1016/j.freeradbiomed.2012.09.027

[77] Lauderback, C.M., Hackett, J.M., Huang, F.F., Keller, J.N., Szweda, L.I., Markesbery, W.R., et al. (2001) The Glial 
Glutamate Transporter, GLT-1, Is Oxidatively Modified by 4-Hydroxy-2-Nonenal in the Alzheimer's Disease Brain: The Role of Abeta1-42. Journal of Neurochemistry, 78, 413-416. http://dx.doi.org/10.1046/j.1471-4159.2001.00451.x

[78] Khan, R.A. (2012) Effects of Launaea procumbens on Brain Antioxidant Enzymes and Cognitive Performance of Rat. BMC Complementary and Alternative Medicine, 12, 219. http://dx.doi.org/10.1186/1472-6882-12-219

[79] Mughal, A. (2010) Acetylcholine and SK Channels Involved in Learning and Memory. http://neurosciencenews.com/actelycholine-sk-channels-learning-memory/

[80] Uddin, M.S., Nasrullah, M., Hossain, M.S., Rahman, M.M., Sarwar, M.S., Amran, M.S., et al. (2016) Evaluation of Nootropic Activity of Persicaria flaccida on Cognitive Performance, Brain Antioxidant Markers and Acetylcholinesterase Activity in Rats: Implication for the Management of Alzheimer's Disease. American Journal of Psychiatry and Neuroscience, 4, 26-37. http://article.sciencepublishinggroup.com/html/10.11648.j.ajpn.20160402.12.html 


\section{Abbreviations}

AD: Alzheimer's disease;

PA: Phyllanthus acidus;

MEPA: Methanolic extract of Phyllanthus acidus;

EPM: Elevated plus maze;

PA: Passive avoidance;

NOR: Novel object recognition;

MWM: Morris water maze;

SOD: Superoxide dismutase;

CAT: Catalase;

GSR: Glutathione reductase;

GST: Glutathione-S-transferase;

GSH: Reduced glutathione;

GSH-Px: Glutathione peroxidase;

TBARS: Thiobarbituric acid reactive species;

ACh: Acetylcholine;

AChE: Acetylcholinesterase;

ITL: Initial transfer latency,

RTL: Retention transfer latency;

TL: Transfer latency;

STL: Step-through latency;

EL: Escape latency;

TSTQ: Time spent in the target quadrant;

TSA: Time spent in the annuli;

DI: Discrimination index;

A $\beta$ : Amyloid- $\beta$;

NFT: Neurofibrillary tangles;

ROS: Reactive oxygen species;

ATCI: Acetyl thiocholine iodide;

DTNB: 5,5-Dithiobis-2-nitrobenzoate ion;

Tris-HCl: Trisfamino methane hydrochloride;

BSA: Bovine serum albumin;

GSH: Glutathione;

EDTA: Ethylenediaminetetraacetic acid;

NADPH: Nicotinamide adenine dinucleotide phosphate;

CDNB: 1-Chloro-2,4-dinitrobenzene;

TCA: Trichloroacetic acid;

TBA: Thiobarbituric acid. 